\title{
Feasibility Testing of a Household Industry Food Production Certificate Using an Expert System with Forward Chaining Method
}

\author{
Irfan Ardiansah ${ }^{1 *}$, Fajri Efatmi ${ }^{2}$, Efri Mardawati ${ }^{3}$, Selly Harnesa Putri ${ }^{4}$ \\ ${ }^{1,2,3,4}$ Department of Agro-Industrial Technology, Universitas Padjadjaran, Bandung, Indonesia
}

\begin{tabular}{l}
\hline Article Info \\
\hline Article history: \\
Received May 15, 2020 \\
Revised November 25, 2020 \\
Accepted November 26, 2020 \\
Published December 30, 2020
\end{tabular}

\section{Keywords:}

Expert System

Feasibility Testing

Food Product

Forward Chaining

Small and Medium Industries

\begin{abstract}
Quality and safe food products are the basic right of every consumer, including food products produced by small and medium industries. Good food production is an important factor in meeting quality standards or food safety licensing requirements. In setting standards, the government also plays an important role in providing direction and assistance to small and medium industries on achieving the specified quality standards. During this time the process is still carried out in a conventional manner directly to the industry. This conventional process is still considered ineffective by seeing the low level of business actors' knowledge of the standards for Good Food Production Practice (GFPP). So, with this lack of knowledge, business actors' interest in making food licensing is low. This study designed the application of an expert system that stimulates and provides an illustration for a standards assessment of Good Food Production methods. This research was conducted using Object Oriented Programming (OOP) engineering method for program development and using forward chaining for reasoning methods. This research proved that the application of an expert system for licensing due diligence can function in accordance with standards set by the government.
\end{abstract}

\section{Corresponding Author:}

Irfan Ardiansah,

Department of Agro-Industrial Technology,

Universitas Padjadjaran,

Jln. Raya Bandung-Sumedang KM. 21, Kecamatan Jatinangor, Kabupaten Sumedang, West Java

Email: irfan@unpad.ac.id

\section{INTRODUCTION}

The economic crisis that hit Indonesia in 1998 was the impact of the decline in the rupiah exchange rate against the dollar. This teaches a lesson that Indonesia needs to have a strong foundation in economic development so that it can survive in a difficult situation. When the monetary crisis hit Indonesia, only the Small and Medium Industry (SMIs) sector was able to survive based on data from Badan Pusat Statistik (BPS) which stated that the number of SMIs in Indonesia did not decrease during the crisis but grew and was able to provide new jobs. This statement shows that SMIs is a business that needs to be supported by the government because it can support the micro and macro economy [1], [2].

In recent years, Indonesia has launched several plans to support the development and innovation of SMI based on the industrial revolution 4.0 using Information Technology (IT). This plan has a major impact on Indonesia's economic growth and the impact is that SMIs must improve the quality and safety of products produced, especially food products to avoid consumer concerns about food safety and potential food contamination [3], [4]. Millennial consumers demand that the food products they consume must have certification and these consumers depend on the government to ensure that the food products consumed are in accordance with the claims promised by the product [5].

The government itself has issued regulations for food-based SMIs to achieve the set standards, but many SMIs still do not understand and understand the contents of these regulations so that it becomes an obstacle to obtaining the required certificates [6]. This can be seen from the minimum level of success of SMI in obtaining food safety certificates, of the 6500 products of the food business in West Bandung, only about 2000 products have legality and only 600 have halal certificates. Failure to obtain legality occurs due to several reasons, 
namely the absence of documents, lack of documents, factoriy locations that do not meet the requirements, bureaucracy and documents handling [7].

Based on this, a web-based expert system design is proposed which is able to simulate the licensing of Produk Industri Rumah Tangga $(P-I R T)$ and provide input to the SMIs if errors are found in the application made, the hope is that food business actors can have a picture of their shortcomings. and complete them before visiting the nearest government integrated services office. This expert system is built with an Object Oriented model and a forward chaining inference system.

A researcher [8] discusses several regions in Indonesia that have successfully implemented an integrated service system to make it easier for food business actors to obtain permits and there have been no sanctions for regions that have not implemented the system, while [9] discusses the lack of awareness of food business vendors in applying for legality even though the government has pro-active by seeking facilitation by picking up files to the regions, as well as providing guidance and capacity building at SMIs. A group of researchers have developed a web-based application to calculate the nutritional value of the food consumed so that users can identify and meet daily nutritional needs based on the user's age, weight and gender [10]. Finally, the challenges in managing food safety are researched by [11], especially management in food production, storage, processing, and logistics so that they can avoid climate change and the emergence of new pathogens that can contaminate food.

\section{RESEARCH METHODOLOGY}

\section{A. Preparation Stage}

The preparation stage is done by collecting data conducted by an interview with related experts to obtain the information needed about the problems and matters needed in the process of making and developing applications.

\section{B. Application Development}

Application development begins with a needs analysis to find out what is needed during the research. Interface Design is made for the interests of aesthetics and ease of use of the application. The inference engine is designed to form a system in accordance with the needs and rules made [12]. The expert system consists of two parts, namely the consulting environment and the development environment. The consulting environment contains components that users use to access the knowledge base and obtain consulting services from experts.

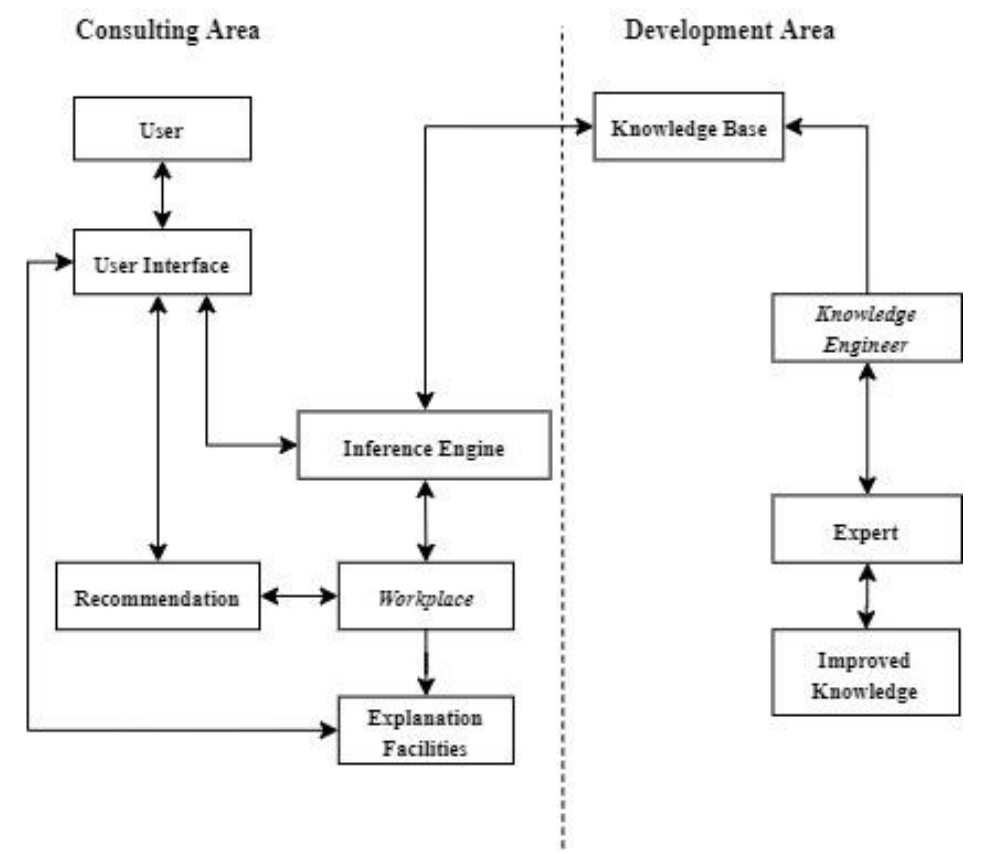

Figure 1. Diagram Logic for Expert System Developed

The development environment is used by administrators to update expert system knowledge, the logic flow can be seen in Figure 1. The knowledge base itself is a rule that contains knowledge to understand the formulation and problem solving that comes from the relevant experts. There are two components of the knowledge base, namely the fact component and the rule component. The fact component is all information 
about the object in the problem area, and the rule component is information on how to get new facts from unknown facts [13].

\section{Final Stage}

The final stage of this research is testing the system using the Black box testing method. It is then continued with a simulation as a user for some experiments. Black box testing works by ignoring the control structure so that its attention is focused on domain information. Black box testing allows software developers to create a set of input conditions that will train all the functional requirements of a program. The advantages of using the black box testing method are tester do not need to have knowledge of programming language and testing is carried out from the user's perspective. This helps to reveal ambiguity or inconsistencies in the requirements specification, and the programmer and tester are both interdependent [12].

\section{RESULTS AND DISCUSSION}

The expert system in this study was designed with engineering methods, the website as an interaction tool by the user that displays the appearance of the application, the system is programmed and developed using Object-Oriented Programming (OOP), while the reasoning of the system uses forward chaining to get the conclusions.

\subsection{Inference Engine Design}

Figure 2 shows the design of an inference engine starting from making rules obtained from interviews with related experts. The reasoning method used is the forward chaining method so that the data starts with existing information and then conclusions are obtained. The inference engine is converted into a web-based application using the PHP programming language and MySQ database server and stored in a cloud server so that it can be accessed by users.

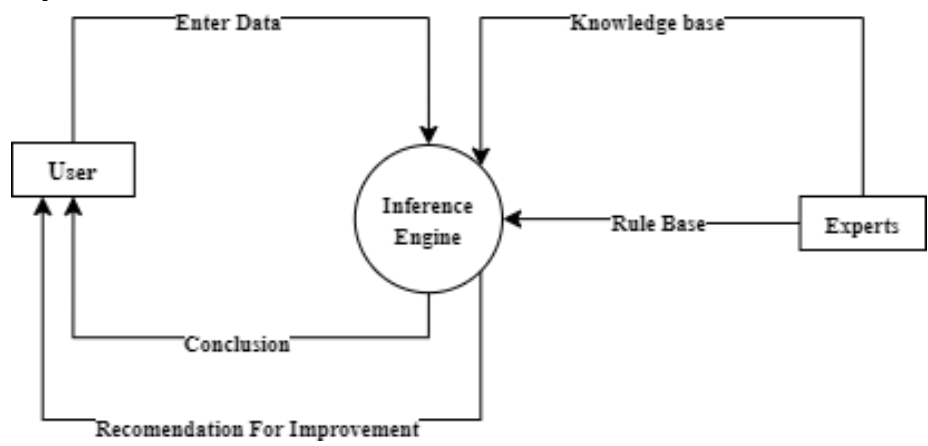

Figure 2. Inference Engine Design Logic

Based on the results of the interview, the knowledge base is obtained. Related experts conduct an assessment on SMIs based on government regulations Nu. 22 of 2018 issued by the Food and Drug Supervisory agency. Table 1 below shows the inspection form that has been converted into a knowledge base by an expert from the Department of Industry.

Table 1. Knowledge Base for SMIs Feasibility Testing

\begin{tabular}{|c|c|c|c|c|c|}
\hline $\mathrm{Nu}$. & THE EXAMINED ELEMENT & \multicolumn{4}{|c|}{ DISCREPANCY } \\
\hline $\boldsymbol{A}$ & LOCATION AND PRODUCTION ENVIRONMENT & MI & MA & & KR \\
\hline 1. & The location and environment of the IRTP are poorly maintained, dirty and dusty & & & & \\
\hline $\boldsymbol{B}$ & BUILDINGS AND FACILITIES & MI & $M A$ & $S E$ & $K R$ \\
\hline 2. & Production space is cramped, difficult to clean, and is used to produce other products than food & & & & \\
\hline 3. & Floor, wall and ceiling, unkempt, dirty, dusty and / or slimy & & & & \\
\hline 4. & Ventilation, doors and windows are poorly maintained, dirty and dusty & & & & \\
\hline$C$ & PRODUCTION EQUIPMENT & MI & MA & $S E$ & $K R$ \\
\hline 5. & Surfaces in direct contact with food are corroded and dirty & & & & \\
\hline 6. & Equipment is poorly maintained, is dirty, and does not guarantee effective sanitation. & & & & \\
\hline 7. & $\begin{array}{l}\text { Measuring instruments / scales for measuring / weighing net weight / net content are not available } \\
\text { or are not accurate. }\end{array}$ & & & & \\
\hline$D$ & WATER SUPPLY OR WATER SUPPLY MEASURES & MI & MA & $S E$ & $K R$ \\
\hline 8. & Clean water is not available in sufficient quantities to meet all production needs & & & & \\
\hline 9. & Water comes from an unsanitary supply & & & & \\
\hline$E$ & HYGIENE AND SANITATION FACILITIES AND ACTIVITIES & MI & $\overline{M A}$ & $S E$ & $\widehat{K R}$ \\
\hline 10. & $\begin{array}{l}\text { Facilities for cleaning / washing foodstuffs, tools, equipment and buildings are not available and } \\
\text { are not well maintained. }\end{array}$ & & & & \\
\hline 11. & Hand washing facilities complete with soap and hand dryer are not available. & & & & \\
\hline 12. & Dirty toilet / latrine facilities are not maintained and are open to production rooms. & & & & \\
\hline 13. & There is no closed landfill available. & & & & \\
\hline $\boldsymbol{F}$ & EMPLOYEE HEALTH AND HYGIENE & MI & MA & $S E$ & $K R$ \\
\hline 14. & $\begin{array}{l}\text { There are employees in the food production department who do not take care of their body } \\
\text { hygiene and or some are sick }\end{array}$ & & & & \\
\hline
\end{tabular}




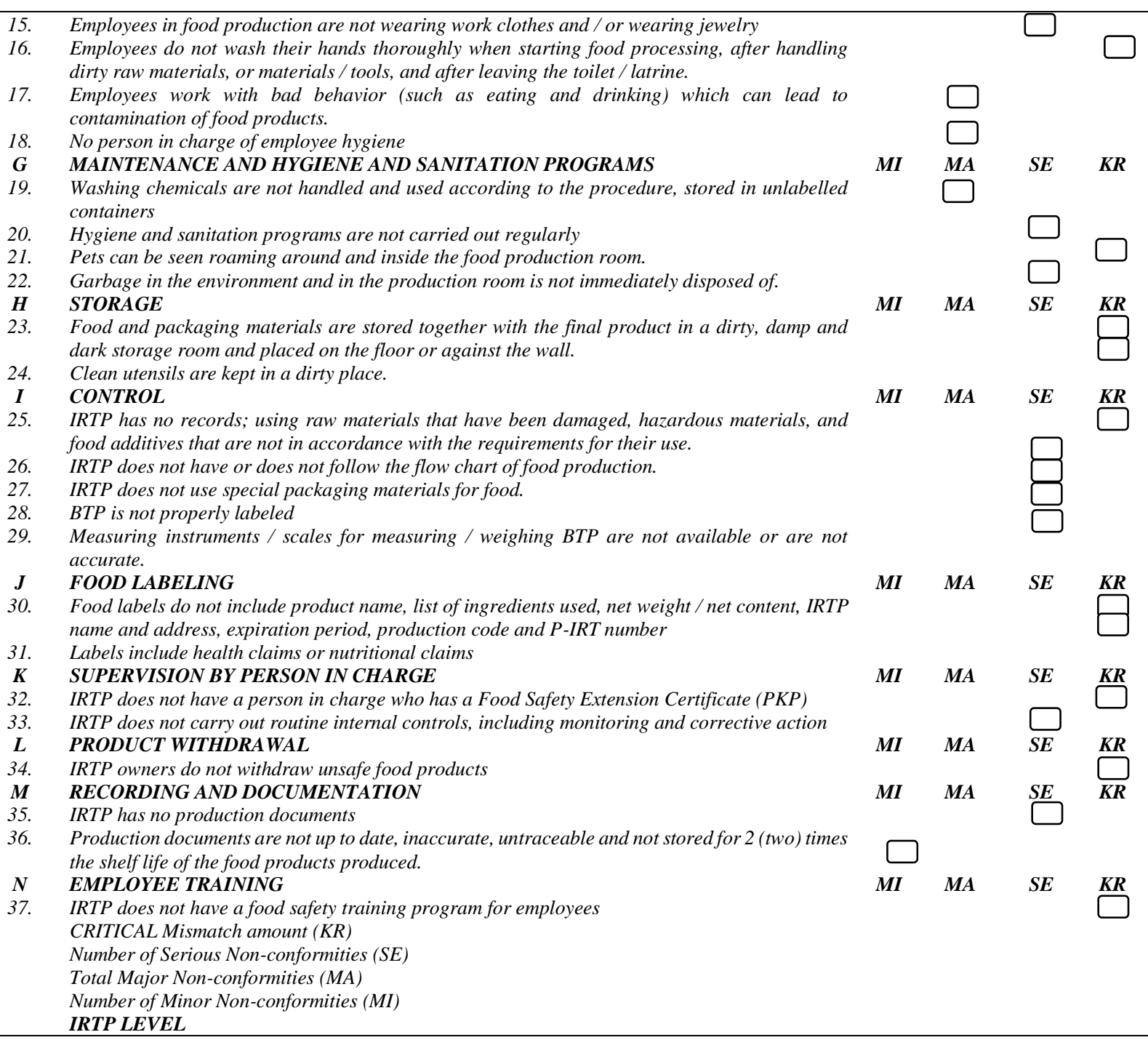

Table 1 is an inspection form that is used as a knowledge base in this study. The table contains statements which are used as references by the government for SMIs. If the statement is in accordance with the condition of production facilities, then a checkmark is given on the inspection form. Each statement has a different level of deviation in accordance with government regulations. The types of deviations are minor deviations, large deviation, serious deviation, and crisis deviations. Minor deviations are deviations from "Persyaratan Dapat" in the provisions of Good Food Production Practices (GFPP), which could potentially affect the quality of SMIs food products. Major deviation is a deviation from the "Persyaratan Sebaiknya" in the provision of GFPP, which has the potential to influence the efficiency of safety control of SMIs food products. Serious deviations are deviations from the "Persyaratan Seharusnya" in the provision of GFPP, which has potential to affect the safety of SMIs food product. While crisis deviation is a deviation from the "Persyaratan Harus" in the provision of GFPP which will affect the safety of SMIs food products directly and/or constitute requirements that must be met. The sum of each level of deviations that occur is a reference to determine the level of the SMIs. This reference is the basis for the rules in the expert system in this study.

The rule base is designed based on provisions made by experts, which determine the level of SMIs. The calculation of the SMIs level category is determined from the existing deviation from the data entered by the user. Table 2 below is a rule base for this expert system.

Table 2. Expert System Rule Base

\begin{tabular}{lcccc}
\hline \multicolumn{1}{c}{ Level IRTP } & \multicolumn{4}{c}{ Total Deviations (Max) } \\
Level I & Minor & Major & Serious & 0 \\
Level II & $0-1$ & $0-1$ & 0 & 0 \\
\hline \hline
\end{tabular}

Feasibility Testing of a Household Industry Food Production Certificate Using an Expert System with 


\begin{tabular}{lcccc}
\hline \multicolumn{1}{c}{ Level IRTP } & Minor & \multicolumn{2}{c}{ Total Deviations (Max) } & Crisis \\
\hline Level III & NA & Major & Serious & 0 \\
Level IV & NA & NA & $1-4$ & $\geq 1$ \\
\hline
\end{tabular}

The rule base on Table 2 above is a table used to determine the level of SMIs. Determination of the level is seen from the number of deviations in the SMIs. SMIs will be included in level I if the conditions of the production facilities of the SMIs have one minor and one major deviation. If there are one or less minor deviations and there are two or three major deviations, then the SMIs that are included are in level 2. SMIs that are included in level 3 are SMIs that have more than 3 major deviations and there are serious deviations equal to or less than four deviations, whereas for level 4, SMIs have more than four serious deviations and there are one or more crisis deviations.

The knowledge base and the rule base are designed in one machine, which is the inference engine. This machine is programmed to become an expert system that can replace the functions of the relevant experts. The mechanism of this inference engine is to receive data from the user and will match the data with the knowledge base in accordance with the rule base. Then, a conclusion will be given. In the implementation of the system, the user will be given a short question and the user should answer the question by choosing "Yes" or "No". The questions that will appear are questions taken on the knowledge base. Examples of question is appeared on Table 3 as follows:

Table 3. Questions embedded on Expert System

\begin{tabular}{cll}
\hline Code & No & \\
\hline A1 & 1 & Is the location kept clean? \\
& 2 & Is the location free of trash and no garbage piled up? \\
& 3 & Does the location have no unpleasant odor? \\
4 & Is the Location Smoke Free? \\
& 5 & Is the location free of dirt and dust? \\
& 6 & Does the location have a closed trash can? \\
$\mathbf{B 2}$ & 7 & Does the IRTP Site have a functioning sewer? \\
& 9 & Is the Production room only used for producing food products? \\
& 10 & Is the room construction made of durable materials? \\
$\mathbf{B 3}$ & 11 & Is the room construction easy to clean? \\
& 12 & Is the floor made of waterproof material? \\
& 13 & Is the floor made of slippery material? \\
& 14 & Is the floor always clean, dustless, dirt free?
\end{tabular}

The questions that will appear are 120 questions in accordance with the rules of Good Food Production Practice for the home industry. This question is a description of the knowledge base. SMIs must answer questions in accordance with the conditions of the SMIs production facilities. After all the questions have been answered, the inference engine will process the data and match it with the knowledge base. If there are deviations or unmatch with the rule base the data will enter the type of deviation in accordance with the knowledge base. The machine will count the number of deviations and provide the conclusion at which level the SMIs is, and then draw a conclusion in accordance with the established rule as seen in Table 4.

Table 4. Scheme for Determining SMIs Level

\begin{tabular}{|c|c|c|c|c|c|c|c|c|c|}
\hline Code & Level I & Level II & Level III & Level IV & Code & Level I & Level II & Level III & Level IV \\
\hline A1 & & & $\sqrt{ }$ & $\sqrt{ }$ & $\mathrm{H} 23$ & & & & \\
\hline B2 & $\sqrt{ }$ & & $\sqrt{ }$ & & $\mathrm{H} 24$ & & & & \\
\hline B3 & & & $\sqrt{ }$ & $\sqrt{ }$ & $\mathrm{I} 25$ & & & & \\
\hline B4 & & & & $\sqrt{ }$ & I26 & & & & \\
\hline C5 & & & & & I 27 & & & & \\
\hline C6 & & & & $\sqrt{ }$ & $\mathrm{I} 28$ & & & & \\
\hline $\mathrm{C} 7$ & & & & $\sqrt{ }$ & I 29 & & & & \\
\hline D8 & & $\sqrt{ }$ & $\sqrt{ }$ & & $\mathrm{J} 30$ & & & & \\
\hline D9 & & & & & K31 & & & & \\
\hline E10 & & $\sqrt{ }$ & $\sqrt{ }$ & & K32 & & & & \\
\hline E11 & & & & $\sqrt{ }$ & K33 & & & & \\
\hline E12 & & & & $\sqrt{ }$ & L34 & & & & \\
\hline E13 & & & & & M35 & & & & \\
\hline E14 & & & & & M36 & $\sqrt{ }$ & $\sqrt{ }$ & & \\
\hline F15 & & & & & N37 & & & & \\
\hline F16 & & \multirow{7}{*}{$\sqrt{ }$} & & $\sqrt{ }$ & Total & 2 & 4 & 7 & 9 \\
\hline F17 & & & $\sqrt{ }$ & & Deviations & & & & \\
\hline F18 & & & \multirow{5}{*}{$\sqrt{ }$} & & Notes: & \multirow{5}{*}{\multicolumn{2}{|c|}{$\begin{array}{l}\text { Minor Deviation } \\
\text { Major Deviation } \\
\text { Serious Deviation } \\
\text { Crisis Deviation }\end{array}$}} & & \\
\hline G19 & & & & \multirow{4}{*}{$\sqrt{ }$} & & & & & \\
\hline G20 & & & & & & & & & \\
\hline G21 & & & & & & & & & \\
\hline G22 & & & & & & & & & \\
\hline
\end{tabular}




\subsection{Interface Design}

Web design on this expert system uses a multi-level user, meaning there are access as an administrator and as a user. The administrator is designed as a user who can edit, delete, and add data, while the user is designed as a user who runs and uses the program that was built [12]. Figure 3a shows a question page containing questions about the condition of SMIs with questions asked based on government regulations. On this page the user answers the SMIs condition with the answer "Yes" or "No" compared to the data in the knowledge base. For user convenience, each page displays 10 questions with a total of 120 questions. The user fills in every question on each page according to the real conditions of SMIs, the user is required to press the Save button before moving to the next page, after all the questions have been answered, the user must press the Finish button so that the system can provide feedback and save the results in the database.
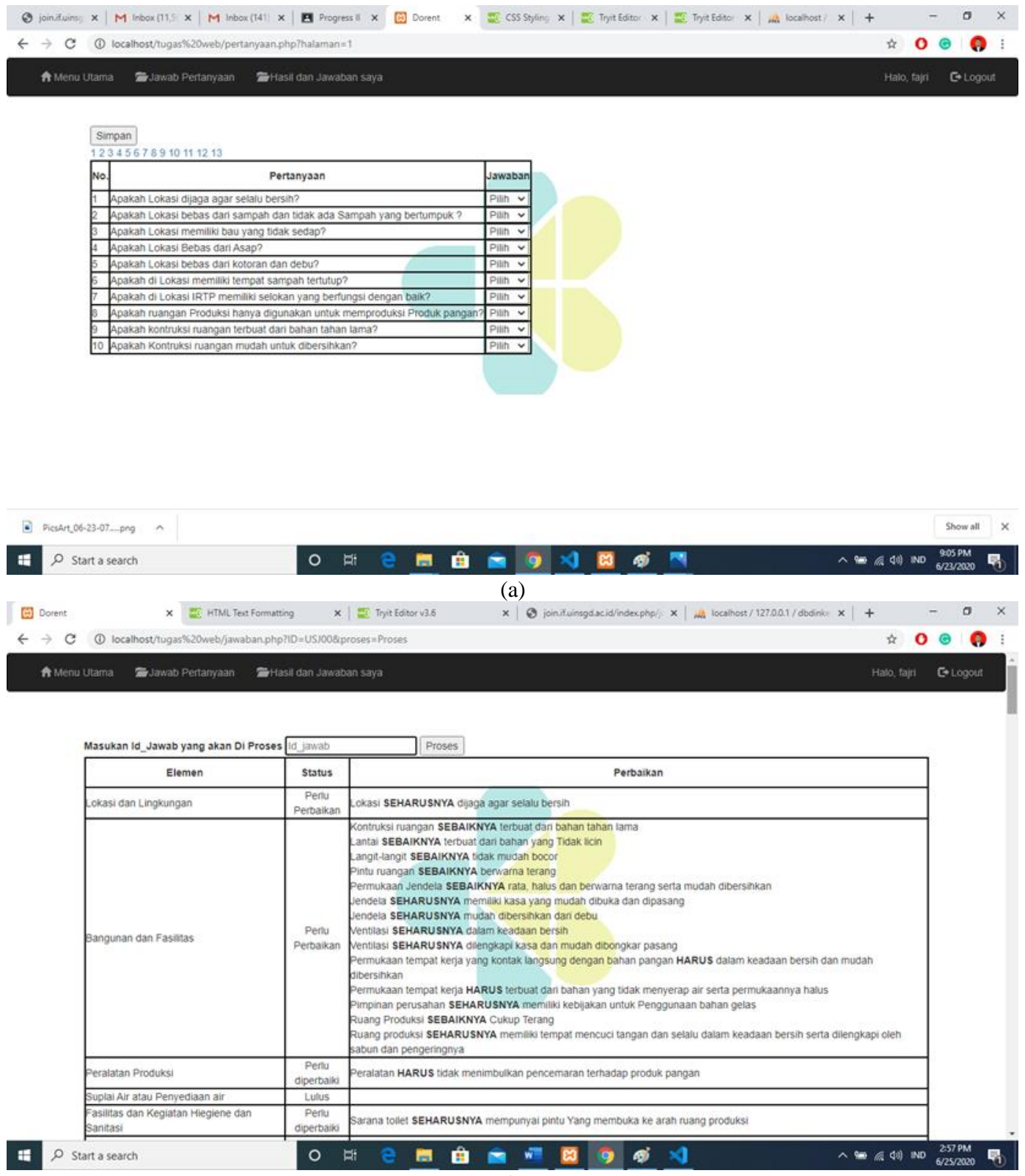

(b)

Figure 3. (a) The question form is given by the system, each user fills the form. (b) An answer form that informs the user which conditions have not been met.

Figure $3 \mathrm{~b}$ displays the results page, showing all user answers sorted by question number and comparing them to the knowledge base. This process can display the results of the assessment and which parts need to be 
fixed along with the solution. The correction column may not be filled if the user's answer matches the knowledge base

\subsection{Result of Testing System Phase}

The final stage of this research is the system testing phase which aims to see whether the application is built in accordance with established standards. The system testing phase uses the Black box testing method. The testing done by this method only focuses on the functional requirements of the device by seeing whether all buttons and commands on the display can function in accordance with their respective functions as seen in Table 5.

Table 5. Black Box Testing of the System

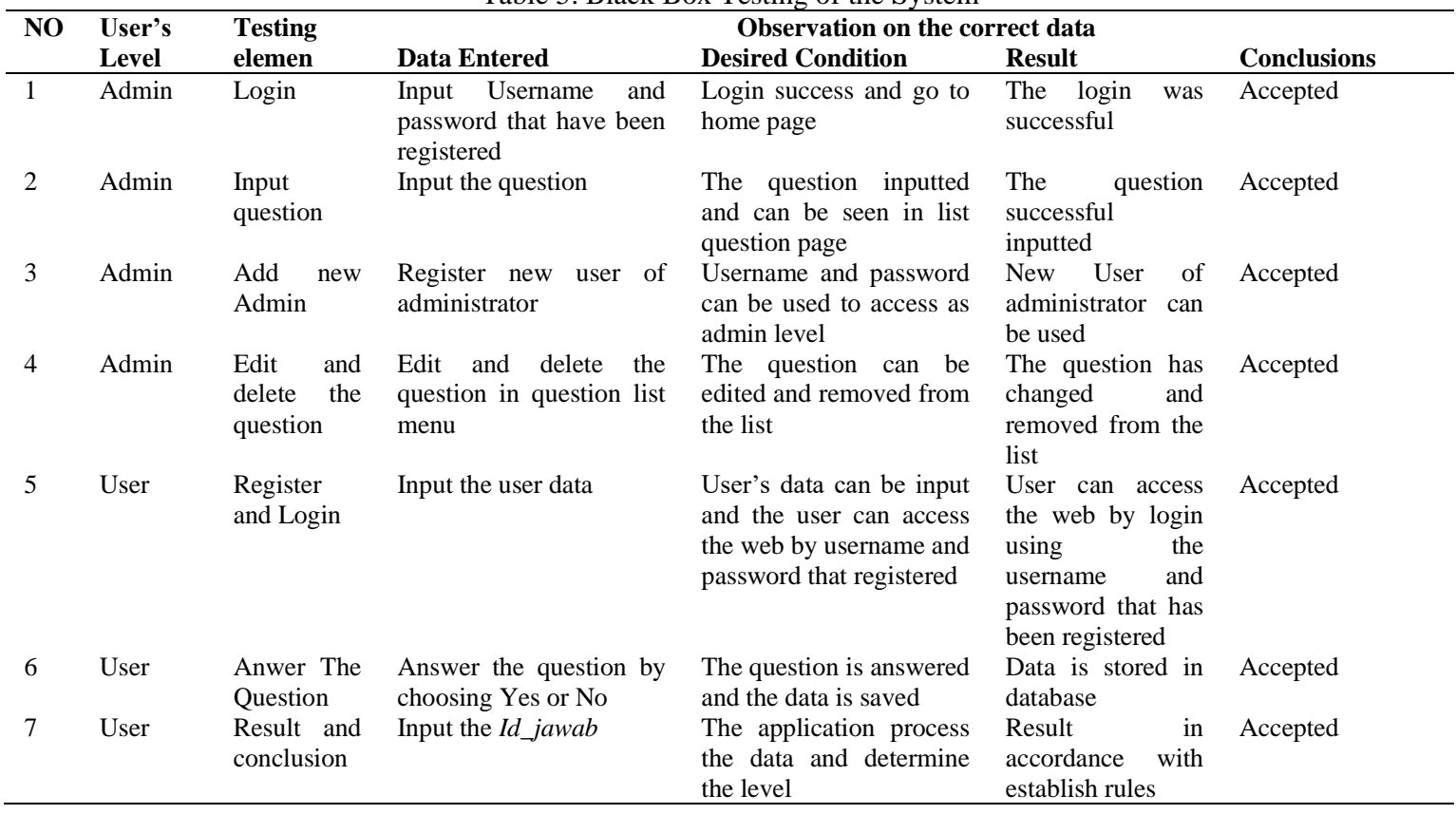

\section{CONCLUSION}

The conclusion of the research design expert system to test the feasibility of a household industry food production certificate using forward chaining method is that the expert system application that was built successfully serves to help SMIs applicatively obtain information about the level of eligibility in implementing food production certificate. This expert system also notifies deviations that are not following standards and provides recommendations to SMIs so that they can easily adjust the state of production facilities following standards set by the government.

\section{REFERENCES}

[1] H. Setiawan, F. Raharjo, and Koesmargono, "Characteristics of small medium contractor entrepreneurs: A study of Indonesia BT - 6th International Conference of Euro Asia Civil Engineering Forum, EACEF 2017, August 22, 2017 - August 25, 2017,” 2017, vol. 138, doi: 10.1051/matecconf/201713805006.

[2] P. Hastuti et al., Kewirausahaan dan UMKM. Yayasan Kita Menulis, 2020.

[3] R. A. Azdy and F. Darnis, "The Small and Medium Enterprise (SME) Promotion Website of Pedado Village BT - 2nd Forum in Research, Science, and Technology, FIRST 2018, October 30, 2018 - October 31, 2018,” 2019, vol. 1167, no. 1, doi: 10.1088/1742-6596/1167/1/012071.

[4] I. Ardiansah, T. Pujianto, and I. I. Perdana, "Penerapan Simulasi Monte Carlo dalam Memprediksi Persediaan Produk Jadi pada IKM Buluk Lupa,” J. Ind. Pertan., vol. 01, no. 03, pp. 61-69, 2019, [Online]. Available: http://jurnal.unpad.ac.id/justin.

[5] S. Al Hakim, D. Indra Sensuse, and Lukman, "Knowledge mapping system features for supporting researcher mobility into industries and sme from e-government perspective BT - International Conference on Information System, Computer Science and Engineering 2018, ICONISCSE 2018, November 26, 2018 - November 27, 2018," 2019, vol. 1196, no. 1, doi: 10.1088/1742-6596/1196/1/012028.

[6] G. Ambrose and P. Harris, Packaging the Brand: The Relationship Between Packaging Design and Brand Identity. Bloomsbury Publishing, 2017.

[7] E. Handayani, I. G. Santi Dewi, W. Purnomo, and A. E. Phitaloka, "The Legality of food packaging to the production of small and medium enterprises (SME) BT - International Conference on Industrial Technology for Sustainable Development 2017, ICon-ITSD 2017, October 25, 2017 - October 26, 2017,” 2018, vol. 175, no. 1, doi: 10.1088/1755-1315/175/1/012191.

[8] S. Susantiningrum, "Pemetaan Permasalahan Yang Dihadapi Oleh Usaha Kecil Menengah (UKM) dan Alternatif 
Solusinya."

[9] H. Kusmanto, W. Warjio, and E. Y. Kurniaty, "Pemberdayaan Usaha Mikro Kecil dan Menengah (UMKM) Ikatan Makanan Olahan (IMO) dalam upaya legalitas usaha," in Unri Conference Series: Community Engagement, 2019, vol. 1, pp. 577-583.

[10] F. M. Shiddieq, R. Kastaman, and I. Ardiansah, "Development of People Food Consumption Patterns information system based on web mobile application," in 2015 3rd International Conference on Adaptive and Intelligent Agroindustry (ICAIA), Aug. 2015, pp. 267-273, doi: 10.1109/ICAIA.2015.7506519.

[11] H. E. Dewi, R. Awaliyah, and H. S. H. Subagyo, "Redesign the layout of agro-industry by using occupational safety and health analysis at tempe chips SME BT - 3rd International Conference on Green Agro-Industry and Bioeconomy, ICGAB 2019, August 26, 2019 - August 27, 2019,”2020, vol. 475, no. 1, p. Indonesian Association of Food Technologist (PATPI); Indonesian Biotechnology Consortium; Indonesian Society for Microbiology (PERMI); Indonesian Society of Agricultural Engineering (PERTETA); Indonesian Society of Agricultural Technologist (APTA); Indonesian Society of Sanitary and Environmental Engineering (IATPI), doi: 10.1088/1755-1315/475/1/012057.

[12] R. S. Pressman and B. R. Maxim, Software Engineering: A Practitioner's Approach. McGraw-Hill Education, 2015.

[13] A. A. Hopgood, Intelligent Systems for Engineers and Scientists. CRC Press, 2016. 